\title{
Dietary Cation-Anion Difference and the Health and Production of Pasture-Fed Dairy Cows. 1. Dairy Cows in Early Lactation
}

\author{
J. R. Roche, ${ }^{\star}+\dagger^{,}{ }^{1}$ D. Dalley, ${ }^{\star}$ P. Moate, ${ }^{\star, 2}$ C. Grainger, ${ }^{*}$ M. Rath, $\dagger$ and F. O'Mara† \\ ${ }^{*}$ Agriculture Victoria Ellinbank, Victoria 3820, Australia \\ †Department of Animal Science and Production, University College Dublin, Ireland
}

\begin{abstract}
Diets offered to lactating dairy cows in the pasturebased dairy systems in southeastern Australia can vary in their dietary cation-anion difference (DCAD) from 0 to $+76 \mathrm{mEq} / 100 \mathrm{~g}$. The effects of such a range of DCAD on the health and production of cows, on a predominantly pasture-based diet, were examined in an indoor feeding experiment. Four groups of five cows were offered a diet of $5 \mathrm{~kg}$ of barley and ad libitum pasture, which is a diet representative of what is offered to cows in early lactation in the region. The cows were supplemented twice daily, with varying levels of salt combinations to alter the $\mathrm{DCAD}$, which ranged from +21 to +127 $\mathrm{mEq} / 100 \mathrm{~g}$. Although a reduction in DCAD to $+21 \mathrm{mEq} /$ $100 \mathrm{~g}$ caused a nonrespiratory systemic acidosis, there was a threshold value, above which blood and urine $\mathrm{pH}$ did not appear affected, although the strong ion difference of blood and urine and the blood bicarbonate concentration increased linearly $(P<0.05,0.001$, and 0.01 , respectively). A DCAD above $+21 \mathrm{mEq} / 100 \mathrm{~g}$ linearly reduced dry matter intake $(P<0.1)$, average daily bodyweight gain $(P<0.05)$, and milk protein yield $(P$ $<0.05$ ) but did not have a significant effect on the concentration of fat, protein, or lactose in milk. Although data were consistent with a tendency for milk yield to decrease as dietary cation-anion differences increased, this trend was not statistically significant. Urine hydroxyproline to creatinine ratio increased $(P<0.001)$ as dietary cation-anion difference increased, possibly suggesting an increased rate of uterine involution. It is concluded that a range in the dietary cation-anion difference, above $+52 \mathrm{mEq} / 100 \mathrm{~g}$, may have deleterious effects on dry matter intake and milk production.
\end{abstract}

(Key words: lactating cow, dietary cation-anion difference, pasture)

\footnotetext{
Received August 28, 2002.

Accepted September 10, 2002.

Corresponding author: J. Roche; e-mail: john.roche@dexcel.co.nz.

${ }^{1}$ Present address: Dexcel, Private Bag 3221, Hamilton, New Zealand.

${ }^{2}$ Present address: University of Pennsylvania, School of Veterinary Medicine, Biostatistics Section, Clinical Science, New Bolton Center, Kennett Square, PA 19348, USA.
}

\begin{abstract}
Abbreviation key: Creat $=$ creatinine, $\mathbf{D C A D}=$ dietary cation-anion difference, $\mathbf{D M D}=$ dry matter digestibility, $\mathbf{H y}=$ hydroxyproline, $\mathbf{M E}=$ metabolizable energy, $\mathbf{S I D}=$ strong ion difference.
\end{abstract}

\section{INTRODUCTION}

In the United States and European dairy industries, where concentrates make up a high proportion of the diet offered to dairy cows, the role of the dietary cationanion difference (DCAD) has been extensively investigated. Much of this research has focused on the periparturient cow and the effect of a reduced DCAD on its health and subsequent production. Little attention has been placed on the effect of DCAD on the lactating cow (Wheeler and Hruska, 1981) even though both Tucker et al. (1988) and West et al. (1991) claim production benefits by raising the DCAD from negative values.

Work done has shown that there is probably an optimum DCAD for maximum milk production. In dairy cows, Tucker et al. (1988) found that milk yield was $9 \%$ higher when a diet with a DCAD of $+20 \mathrm{mEq} / 100 \mathrm{~g}$ was fed compared with a DCAD of $-20 \mathrm{mEq} / 100 \mathrm{~g}$. The optimum DCAD for lactating dairy cows based on National Research Council (2001) values for $\mathrm{Na}, \mathrm{K}$, and $\mathrm{Cl}$ is approximately $+23 \mathrm{mEq} / 100 \mathrm{~g}$, an optimum not too far removed from the findings of Tucker et al. (1988). Research on alternative species supports the view that there is an optimum DCAD for production (Mongin, 1980; Yen et al., 1981).

West et al. (1991) reported increases in milk yield from dairy cows up to a DCAD of $+32.4 \mathrm{mEq} / 100 \mathrm{~g}$, irrespective of weather influences. Their results, under hot conditions, support the earlier work of Escobosa et al. (1984), where a reduction in milk production was found in cows that had been supplemented with anions $\left(2.28 \% \mathrm{CaCl}_{2}\right)$. Schneider et al. (1986) showed greater production from heat-stressed cows if dietary K levels were above National Research Council (1989) recommended levels. A later study (West et al., 1992) showed a linear increase in DMI as DCAD increased to +46 $\mathrm{mEq} / 100 \mathrm{~g}$, and it was concluded that increasing the DCAD was more influential in this than the actual cation involved. 
Delaquis and Block (1995) found no benefit to increasing the DCAD offered to cows in late lactation, although significant benefits were observed in early- and midlactation through increased DMI and milk production. However, the DCAD offered to cows in early- and midlactation was substantially less than that offered to the late lactation cows (Delaquis and Block, 1995). The lowest DCAD offered to the cows in late lactation $(+19.98 \mathrm{mEq} / 100 \mathrm{~g})$ may have been too high to expect a difference (Roche et al., 2000). Sanchez and Beede (1994) analyzed the data from 10 macromineral trials and found an optimum DCAD for intake and lactation to be between +25 and $+50 \mathrm{mEq} / 100 \mathrm{~g}$.

The dairy industry in southeastern Australia is largely perennial ryegrass-based and supplemented with cereal grains, pasture hay, and pasture silage (Doyle et al., 1996). Roche et al. (2000) reported that the DCAD can range from 0 to $+76 \mathrm{mEq} / 100 \mathrm{~g}$ and Jacobs and Rigby (1999) found that the DCAD offered could be as high as $+100 \mathrm{mEq} / 100 \mathrm{~g}$. Little local information is available on whether this variation in DCAD is significantly affecting milk production, either positively or negatively, even though Morton and Roach (2002) reported reduced DMI in high $\mathrm{K}$ pastures in New Zealand.

The objectives of this experiment were to determine the effects of altering the DCAD of a perennial ryegrass and cereal grain diet and to examine the effects on milk production, acid-base balance, and blood and urine parameters of dairy cows in early lactation.

\section{MATERIALS AND METHODS}

The experiment was conducted at Agriculture Victoria Ellinbank $\left(37^{\circ} 50^{\prime} \mathrm{S}, 145^{\circ} 00 \mathrm{E}\right)$ approximately 110 $\mathrm{km}$ southeast of Melbourne, Victoria, and lasted $19 \mathrm{~d}$ during September and October, 1997.

All procedures in this study were approved by the Ellinbank Animal Ethics Committee (Victoria, Australia) and animals were handled according to the Code of Practice for the Care and Use of Animals for Experimental Purposes (Australian Government, 1990).

\section{Experimental Design and Treatments}

Twenty multiparous Holstein-Friesian cows, $25 \pm 8$ $\mathrm{d}$ (mean \pm standard deviation) postcalving, were randomly allocated to four dietary treatments (Genstat V, 1997) in a randomized block design. Cows were allocated randomly to treatment using Baird's method (Baird, 1994; Harville, 1974) on the basis of preexperimental milk yield, total production for the previous lactation, age and liveweight.

\section{Feeds}

All cows were offered a daily diet of $5 \mathrm{~kg}$ DM of dryrolled barley and ad libitum pasture, in two feeds offered twice daily following milking. Ad libitum was defined as $110 \%$ of the amount that had been eaten the previous day. The nutritive characteristics and mineral concentrations of the feeds offered are given in Table 1.

\section{Dietary Cation-Anion Difference}

The diet was supplemented with salts of either $\mathrm{Na}$, $\mathrm{Cl}$, or $\mathrm{S}$ such that four treatments received a planned DCAD $((\mathrm{Na}+\mathrm{K})-(\mathrm{Cl}+\mathrm{S}))$ of $+20,+45,+70$ and +95 $\mathrm{mEq} / 100 \mathrm{~g}$. DCAD is the difference, in milliequivalents, between certain cations and anions in the diet and is calculated by subtracting the milliequivalents of anions from the milliequivalents of cations, in all feeds. The equation most commonly used contains only two cations ( $\mathrm{Na}$ and $\mathrm{K}$ ) and two anions ( $\mathrm{Cl}$ and $\mathrm{S}$ ) (Tucker et al., 1992).

$$
\mathrm{DCAD}=(\mathrm{Na}+\mathrm{K})-(\mathrm{Cl}+\mathrm{S})(\mathrm{mEq} / 100 \mathrm{~g} \mathrm{DM})
$$

The basal DCAD, based on previous work (Roche et al., 2000), was assumed to be approximately $+30 \mathrm{mEq} /$ $100 \mathrm{~g} \mathrm{DM}$. Table 2 shows the salts used and the daily quantities that were administered. $\mathrm{MgSO}_{4}$ $\left(\mathrm{MgSO}_{4} \cdot 7 \mathrm{H}_{2} \mathrm{O}\right)$ and $\mathrm{MgCl}_{2}\left(\mathrm{MgCl}_{2} \cdot 6 \mathrm{H}_{2} \mathrm{O}\right)$ were used to reduce the DCAD and $\mathrm{NaHCO}_{3}$ was used to increase it. $\mathrm{NaHCO}_{3}$ was chosen to increase the DCAD as it is the most commonly supplemented cationic salt used in Australia. The research of West et al. (1992) showed that cation source ( $\mathrm{Na}$ or $\mathrm{K}$ ) was not important. $\mathrm{MgO}$ and $\mathrm{CaCO}_{3}$ were used to balance the dietary $\mathrm{Mg}$ and dietary Ca concentrations, respectively. Dietary Ca was $1.0 \% \mathrm{DM}$ and dietary $\mathrm{Mg}$ was $0.4 \% \mathrm{DM}$.

The cows received their appropriate salt mixture, twice daily, at 0615 and $1515 \mathrm{~h}$. If DCAD is to be accurately manipulated in pasture-based systems it will be through supplementation of cows with appropriate salt mixtures once or twice daily, as the consistent and predictable manipulation of $\mathrm{DCAD}$ has been shown to be very difficult (Roche et al., 2002). Furthermore the pasture-based system, where cows are generally a considerable distance from supplementation facilities precludes a more frequent supplementation strategy. In support of this method, Roche (1999) showed increased calcium absorption and urinary calcium excretion and little or no diurnal variation in urine $\mathrm{pH}$ when anionic salts were supplemented twice daily to reduce the DCAD to $-20 \mathrm{mEq} / 100 \mathrm{~g}$, thereby suggesting that twice daily supplementation of anionic salts in pasture-based systems had similar effects to continuous supplementation in a TMR. 
ROCHE ET AL.

Table 1. Mean DM (\%) and nutrient analysis (\% DM) of the feeds offered.

\begin{tabular}{|c|c|c|c|c|c|c|c|c|c|c|c|}
\hline & $\mathrm{DM}$ & $\mathrm{CP}$ & $\mathrm{DMD}^{1}$ & $\mathrm{ME}^{2}$ & $\mathrm{~K}$ & $\mathrm{Na}$ & $\mathrm{Cl}$ & $\mathrm{S}$ & $\mathrm{Mg}$ & $\mathrm{Ca}$ & $\mathrm{P}$ \\
\hline Pasture & 13.2 & 21.4 & 82 & 2.84 & 4.1 & 0.21 & 1.17 & 0.30 & 0.22 & 0.39 & 0.37 \\
\hline Barley & 88.4 & 13.0 & 77 & 2.68 & 0.5 & 0.19 & 0.19 & 0.12 & 0.15 & 0.04 & 0.28 \\
\hline
\end{tabular}

As the DCAD of the diet was high, and the amounts of salts required to reduce or increase it to the predetermined levels were so great, the salts used were administered orally in solution with a stomach tube. This stomach tube consisted of a length of rigid plastic piping (400 $\mathrm{mm}$ in length and $19 \mathrm{~mm}$ in diameter) attached to a flexible tube, $1 \mathrm{~m}$ in length, which was in turn attached to a 2 -L container. There was a small hole (1 $\mathrm{mm}$ ) in the container, which allowed air to enter and help the salt suspension to flow down the tube and into the cow's esophagus.

\section{Animals and Feeds}

The cows were milked at 0600 and $1500 \mathrm{~h}$ each day and received their salt supplement immediately postmilking. After receiving their salt supplement, the cows were allowed access to half their daily allocation of barley for 20 min before being allowed access to fresh pasture. Cows were individually fed for the duration of the experimental period. Pasture was offered daily for two 5 -h periods. At 1200 to $1445 \mathrm{~h}$ and 2100 to $0545 \mathrm{~h}$ the cows were held as a single group on a bare paddock where water was available ad libitum.

The pastures used in this experiment had not been grazed for 6 to $7 \mathrm{wk}$ and were harvested at a mass of approximately $2500 \mathrm{~kg} \mathrm{DM} / \mathrm{ha}$. The pasture was cut to approximately $40 \mathrm{~mm}$, twice daily, and collected using a loader wagon. The cut pasture was not chopped further so as to best represent grazed pasture. The sward consisted of approximately $70 \%$ perennial ryegrass (Lolium perenne L.), 25\% other grasses (Dactylus glomerata, Holcus lanatus and some Poa species), 2.5\% white clover (Trifolium repens) and $2.5 \%$ weeds on a

Table 2. Quantities of salt (g) administered daily to alter the dietary cation-anion difference (DCAD) and balance the diets for $\mathrm{Ca}$ and $\mathrm{Mg}$ concentration.

\begin{tabular}{lrrrr}
\hline $\mathrm{DCAD}, \mathrm{mEq} / 100 \mathrm{~g}$ & +21 & +52 & +102 & +127 \\
\hline $\mathrm{NaHCO}_{3}$ & 0 & 125 & 525 & 930 \\
$\mathrm{MgSO}_{4} \cdot 7 \mathrm{H}_{2} \mathrm{O}$ & 205 & 0 & 0 & 0 \\
$\mathrm{MgCl}_{2} \cdot 6 \mathrm{H}_{2} \mathrm{O}$ & 170 & 0 & 0 & 0 \\
$\mathrm{MgO}_{\mathrm{CaCO}}$ & 0 & 60 & 60 & 60 \\
\hline
\end{tabular}

DM basis. The hay was chopped to approximately 3 to $5 \mathrm{~cm}$ using a New Holland 717 flail harvester and the barley was dry rolled before feeding.

\section{Measurements}

Cows were manually stimulated to urinate 3 times each week and a sample of urine, from midstream, was collected in a $30-\mathrm{ml}$ container. Within $30 \mathrm{~min}$ of collection, $\mathrm{pH}$ was measured and $10 \mathrm{ml}$ of sample was frozen for mineral, hydroxyproline (Hy) and creatinine analysis. Urine minerals were determined by inductively coupled plasma emission spectrometry having been diluted with $1 \%$ nitric acid. Urine $\mathrm{Hy}$ was determined by a method developed by Parekh and Jung (1970) using a microplate reader (Biorad 550, BioRad, Hercules, CA). Urine creatinine was determined by a procedure modified from Bartels et al. (1972), using an autoanalyzer (Boehringer Manheim Hitachi 911).

Blood from the jugular vein was collected from each cow twice weekly for the duration of the experiment. Two samples were taken at each sampling. One sample was taken using a 10-ml heparinized syringe. Any excess air was immediately removed along with approximately $1 \mathrm{ml}$ of blood, and the syringe was stoppered and placed on ice. This aliquot was used to determine blood $\mathrm{pH}, \mathrm{pCO}_{2}$, and $\mathrm{pO}_{2}$ within 20 min of sampling, using a blood gas analyzer (Geprufte Sichereit, Italy). The second sample, taken using a $10-\mathrm{ml}$ heparinized evacuated tube, was centrifuged for $10 \mathrm{~min}$ at $1120 \times$ $g$. Following centrifugation the plasma was pipetted off and frozen awaiting mineral and creatinine analysis. Plasma minerals were determined by inductively coupled plasma emission spectrometry having been digested using nitric acid assisted microwave digestion (Milestone Application Laboratory, 1995).

Individual milk yields were recorded daily (Alpro milk meter system. Alfa Laval, Sweden). Fat, protein, and lactose concentrations of milk were determined by Milkoscan (Foss Electric, Hillerød, Denmark) on individual p.m. and a.m. aliquot samples collected for $2 \mathrm{~d}$ each week.

Pasture offered and refused for each cow was measured daily and DMI calculated. Representative samples of each feed offered and refused were dried at $105^{\circ} \mathrm{C}$ 
Table 3. The effect of a range of dietary cation-anion differences (DCAD) on the plasma mineral concentration $(\mathrm{mg} / \mathrm{l})$ of lactating cows.

\begin{tabular}{lccccr}
\hline $\mathrm{DCAD}, \mathrm{mEq} / 100 \mathrm{~g}$ & +21 & +52 & +102 & +127 & SEM \\
\hline $\mathrm{Ca}$ & 100.3 & 99.9 & 99.4 & 98.3 & 2.9 \\
$\mathrm{Mg}$ & 19.0 & 19.0 & 19.4 & 17.7 & 1.3 \\
$\mathrm{~K}$ & 222.7 & 218.7 & 218.3 & 217.8 & 6.6 \\
$\mathrm{Na}$ & 2761 & 2933 & 3000 & 3011 & 94 \\
$\mathrm{Cl}$ & 3650 & 3377 & 3380 & 3444 & 148 \\
$\mathrm{~S}$ & $1093^{\mathrm{b}}$ & $1039^{\mathrm{ab}}$ & $1073^{\mathrm{ab}}$ & $989^{\mathrm{a}}$ & 31 \\
\hline
\end{tabular}

${ }^{\mathrm{a}, \mathrm{b}}$ Means in a row with different superscripts differ significantly $(P<0.05)$.

to constant weight to determine DM content. Samples of all feeds were bulked on a weekly basis and dried at $65^{\circ} \mathrm{C}$ for $72 \mathrm{~h}$, ground to pass through a $0.5 \mathrm{~mm}$ sieve (Christy Lab Mill, UK) and analyzed for in vitro dry matter digestibility (DMD), nitrogen, and macrominerals. DMD was determined by the method of Clarke et al. (1982). Metabolizable energy (ME; Mcal/kg DM) was calculated from DMD : $\mathrm{ME}=\left(\left(\mathrm{DMD}^{*} 0.17\right)-2\right) / 4.186$; (Standing Committee on Agriculture, 1990).

The nitrogen content was determined by a Kjeldahl method using Buchi Kjeldahl nitrogen apparatus and $\mathrm{CP}$ was calculated from nitrogen $\left(\mathrm{CP}=\mathrm{N}^{*} 6.25\right)$. Macrominerals were determined using X-ray spectroscopy (Hutton and Norrish, 1977; Norrish and Hutton, 1977).

\section{Calculations and Statistical Analysis}

Urinary minerals ( $\mathrm{Ca}, \mathrm{Mg}, \mathrm{Na}, \mathrm{Cl}, \mathrm{S}$ ) and $\mathrm{Hy}$ were expressed as ratios to creatinine concentration (Creat) to overcome variations in urine volume among animals (Roche et al., 2002).

The strong ion difference [SID] is the difference, in milliequivalents, between certain cations and anions in body fluids and is calculated by subtracting the milliequivalents of $\mathrm{Cl}$ and $\mathrm{S}$ from the milliequivalents of $\mathrm{Na}$ and $\mathrm{K}$, in either plasma or urine ( $\left[\mathrm{SID}_{\mathrm{b}}\right]$ and $\left[\mathrm{SID}_{\mathrm{u}}\right]$, respectively).

The DCAD was calculated using the equation of Tucker et al. (1992) using the quantities of the salts administered and the measured mineral concentrations and DMI of all feeds.

$$
\mathrm{DCAD}=(\mathrm{Na}+\mathrm{K})-(\mathrm{Cl}+\mathrm{S})(\mathrm{mEq} / 100 \mathrm{~g} \mathrm{DM}) .
$$

Blood bicarbonate concentration was calculated from blood $\mathrm{pH}$ and $\mathrm{pCO}_{2}$ using the equations outlined by Tietz (1987).

All data were analyzed by analysis of variance using Genstat V (1997) with cows as the experimental unit. For each cow, daily milk yields were averaged over a 14-d period beginning $5 \mathrm{~d}$ after the onset of treatment. These data were analyzed using Genstat 5.4.1 (Genstat $\mathrm{V}$, 1997) software according to a statistical model, which included effects for the four levels of treatment, linear, quadratic, and cubic trends with increasing DCAD and a covariate for pretreatment milk yield.

\section{RESULTS}

The measured cation anion differences (CAD) of the diets eaten by the cows on each treatment were +21 ( \pm $5),+52( \pm 5),+102( \pm 10)$, and $+127( \pm 14) \mathrm{mEq} / 100 \mathrm{~g}$ (mean \pm standard deviation).

The effects of the range of $\mathrm{DCAD}$ on blood $\mathrm{pH}$, bicarbonate concentration, $\mathrm{pCO}_{2}, \mathrm{pO}_{2}$, and $\left[\mathrm{SID}_{\mathrm{b}}\right]$ are shown in Figure 1. There was a curvilinear reduction in blood $\mathrm{pH}(P<0.05)$ as DCAD decreased and the cows receiving $+21 \mathrm{mEq} / 100 \mathrm{~g}$ had a significantly lower blood $\mathrm{pH}(P<$ $0.001)$ than the other three treatments, which did not differ from each other. $\left[\mathrm{SID}_{\mathrm{b}}\right]$ and bicarbonate concentration decreased linearly $(P<0.05$ and 0.01 , respectively) with decreasing $\mathrm{DCAD}$ but blood $\mathrm{pCO}_{2}$ or $\mathrm{pO}_{2}$ were not affected by treatment. There was no significant effect of treatment on plasma mineral concentration (Table 3) apart from plasma S, which declined with increasing DCAD $(P<0.1)$. The effects of a change in DCAD on urine parameters are shown in Figure 2. Urine $\mathrm{pH}$ declined curvilinearly $(P<0.001)$ while [SIDu] decreased linearly $(P<0.05)$ with decreasing $\mathrm{DCAD}$. The cows receiving the $+21 \mathrm{mEq} / 100 \mathrm{~g}$ treatment had a significantly lower urine $\mathrm{pH}$ than the other treatments $(P<0.001)$, which did not differ from each other. $\mathrm{Na}$ /creat increased linearly $(P<0.001)$ as DCAD increased, while $\mathrm{Cl} / \mathrm{Creat}$ and $\mathrm{S} / \mathrm{Creat}$ decreased curvilinearly with decreasing DCAD $(P<0.001$ and 0.01 , respectively). Hy/Creat increased linearly $(P<0.001)$ with increasing DCAD.

The reduction in total DMI as DCAD increased (Figure 3 ) approached significance $(P<0.1)$, but the change in DCAD did not have a significant effect on the yield or concentration of milk fat or lactose or on the concentration of milk protein (Table 4). The yield of protein in milk was significantly lower in the highest DCAD treatment group when compared with the two lowest DCAD treatment groups. Data were consistent with a tendency for milk yield to decrease as DCAD increased, 

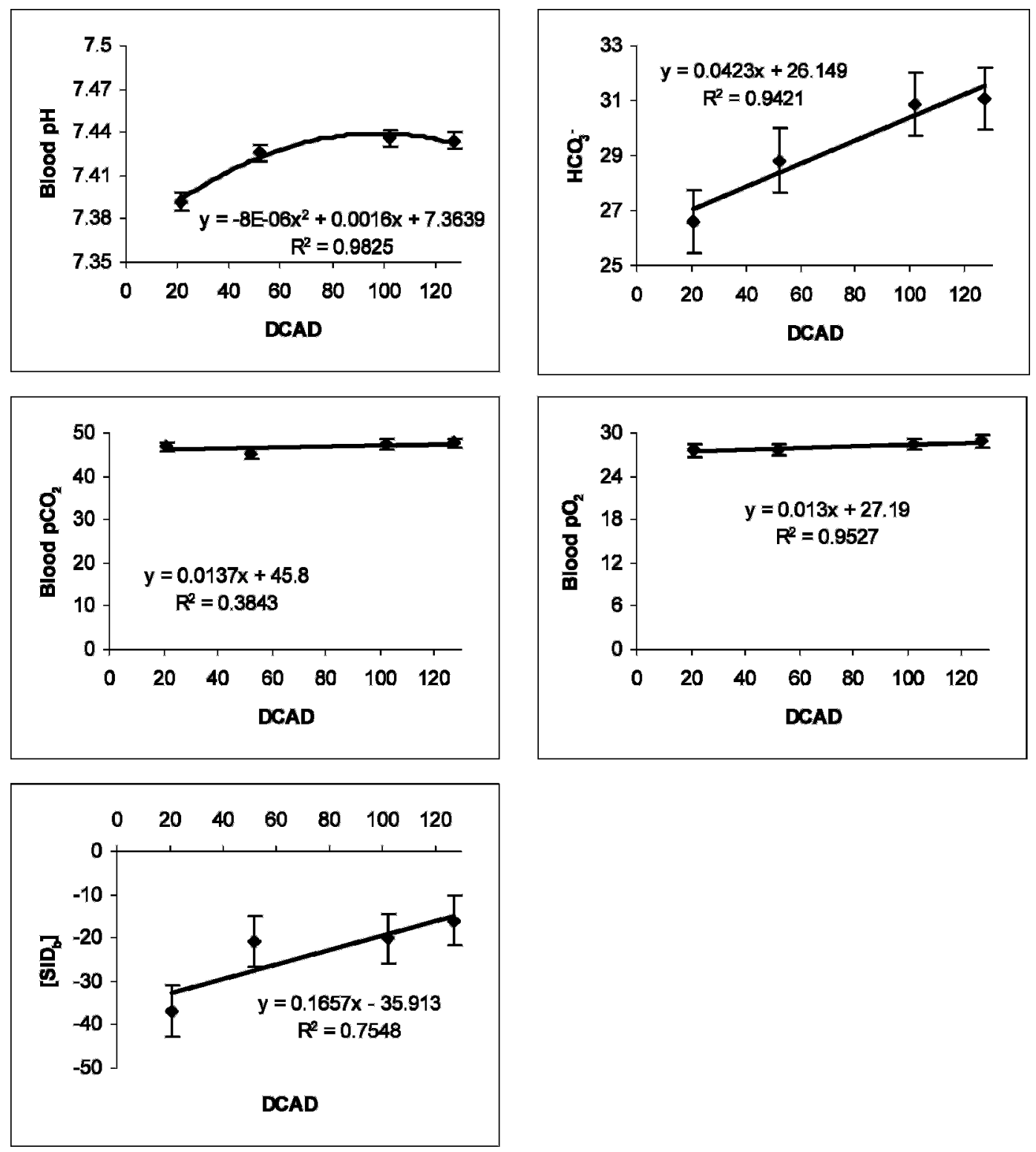

Figure 1. The effect of a range of dietary cation-anion differences ( $\mathrm{DCAD}, \mathrm{mEq} / 100 \mathrm{~g})$ on the blood $\mathrm{pH}, \mathrm{pCO}_{2}(\mathrm{Torr})$ and $\mathrm{pO} \mathrm{O}_{2}(\mathrm{Torr})$, bicarbonate $(\mathrm{mEq} / \mathrm{L})$ and the strong ion difference of blood $\left(\left[\mathrm{SID}_{\mathrm{b}}\right]\right)$.

but the trend was not statistically significant (Table 4). Daily BW gain decreased linearly $(P<0.05)$ with increasing DCAD (Figure 3).

\section{DISCUSSION}

In much of the previous lactating cow work the DCAD has been calculated using:

$$
(\mathrm{Na}+\mathrm{K})-\mathrm{Cl} \quad(\text { Mongin, 1980) }
$$

However, the findings of Tucker et al. (1992) suggest that $\mathrm{S}$ should also be subtracted in the equation. West
(1993) claims that the original equation is sufficient because most work shows an increase in production by going from a lower DCAD to a higher one. Therefore, acidogenic materials are not as important in the equation as alkalinogenic ions. When the base DCAD is low, this may be correct, but where a high $\mathrm{K}$ forage is the main feed, the DCAD is often higher (Roche et al., 2000) than that regarded as optimum by Sanchez and Beede (1994) and in such a situation, S may be important. For this reason, the equation used to calculate DCAD in this work was the one proposed by Tucker et al. (1992):

$$
(\mathrm{Na}+\mathrm{K})-(\mathrm{Cl}+\mathrm{S})
$$



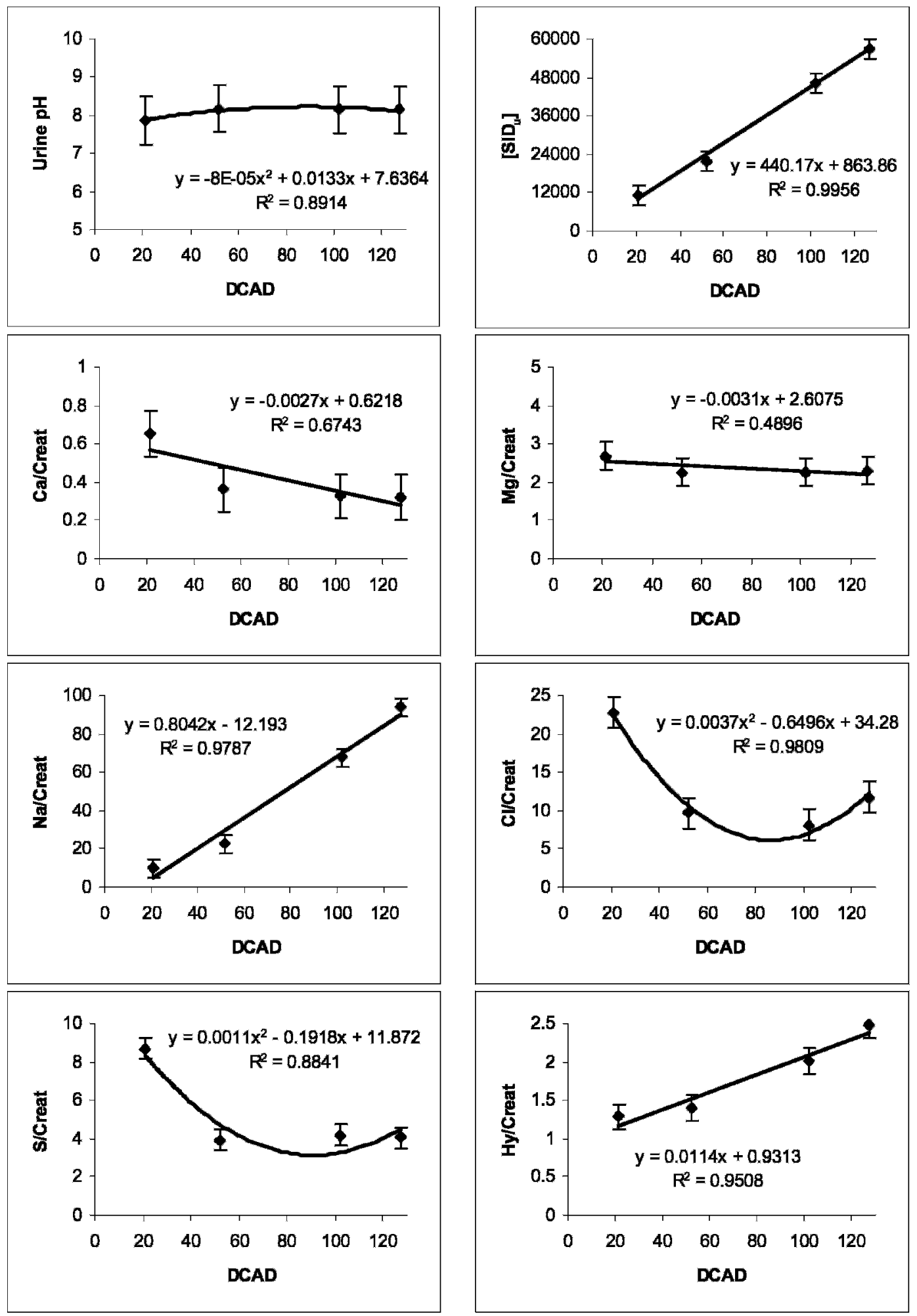

Figure 2. The effect of a range of dietary cation-anion differences (DCAD, $\mathrm{mEq} / 100 \mathrm{~g}$ ) on urine $\mathrm{pH}$, the strong ion difference of urine ([SID $\mathrm{u}])$ and mineral $(\mathrm{Ca}, \mathrm{Mg}, \mathrm{Na}, \mathrm{Cl}, \mathrm{S})$ and hydroxyproline $(\mathrm{Hy})$ to creatinine (/Creat) ratios. 

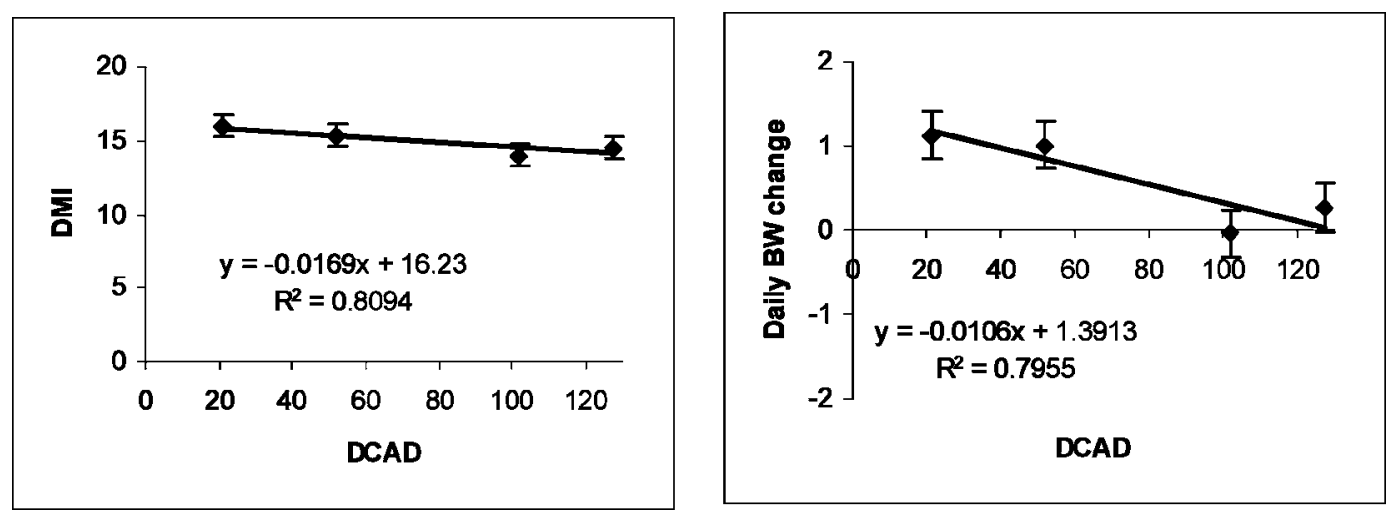

Figure 3. The effect of a range of dietary cation-anion differences $(\mathrm{mEq} / 100 \mathrm{~g})$ on DMI (kg/c/d) and daily BW change (kg/d).

The lowest DCAD offered to the cows in this experiment caused a nonrespiratory systemic acidosis, supporting the conclusions of Stewart $(1981,1983)$ that an increased dietary concentration of $\mathrm{Cl}$ and $\mathrm{S}$ would reduce the $\mathrm{pH}$ of body fluids. However, although $\left[\mathrm{SID}_{\mathrm{b}}\right]$ and bicarbonate concentration changed linearly with changing DCAD, there appears to be a threshold DCAD above which a change in blood $\mathrm{pH}$ does not occur (Figure 1). This demonstrates the ability of the body to withstand large changes in its internal environment without influencing systemic $\mathrm{pH}$. Considering the quantities of acids entering the body daily via ingestion and metabolic reactions and the necessity to maintain a relatively constant systemic $\mathrm{pH}$ for optimal body function (Roche, 1999), this buffering ability is of paramount importance. The threshold DCAD above which blood $\mathrm{pH}$ is not greatly affected on a pasture-based system appears to be somewhere in excess of $+52 \mathrm{mEq} / 100 \mathrm{~g}$. However, it is not possible to ascertain its exact value from this experiment. The existence of a threshold was not evident from previous work (Escobosa et al., 1984; Tucker et al., 1988; West et al., 1991) presumably because the upper DCAD was not high enough to determine whether or not a change in blood $\mathrm{pH}$ would occur.
Additionally, Figure 2 shows a concomitant, but larger, change in the $\mathrm{pH}$ of excreted urine when blood $\mathrm{pH}$ changes, demonstrating the ability of the kidneys to remove the metabolic challenge. However, urine $\mathrm{pH}$ cannot drop indefinitely and, in fact, has a threshold limit of 4.5 (Roche, 1999). A linear reduction in $\left[\operatorname{SID}_{\mathrm{u}}\right.$ ] with decreasing $\mathrm{DCAD}$, while $\mathrm{pH}$ is reduced curvilinearly illustrates the capacity of urine to resist changes in $\mathrm{pH}$.

In this research on a pasture-based diet, a change in DCAD between +21 and $+127 \mathrm{mEq} / 100 \mathrm{~g}$ did not significantly affect the yield of milk or the concentration of fat, protein or lactose in milk. Although not significant, mean milk yields did decrease as the DCAD increased and were consistent with a real trend existing. The linear decrease in total dry matter intake $(P<0.1)$, which is supported by recent research in pasture-fed cows in New Zealand (Morton and Roach, 2002), and daily BW gain $(P<0.05)$ as DCAD increased supports the trend towards decreased milk production at higher $\mathrm{DCAD}$. The lack of a significant difference in milk yields can probably be attributed to the high standard error of the mean, which is probably due to small numbers of cows per treatment. This reduced milk yield and

Table 4. The effect of dietary cation-anion difference (DCAD) on the 14-d mean yield of milk, fat, protein, and lactose and on the 14-d mean concentration of fat, protein, and lactose from dairy cows offered pasture and barley in early lactation.

\begin{tabular}{lccccc}
\hline DCAD, $\mathrm{mEq} / 100 \mathrm{~g}$ & +21 & +52 & +102 & +127 & SEM \\
\hline Yield, kg/c/d & & & & & \\
Milk & 25.4 & 24.6 & 24.7 & 23.2 & 1.3 \\
Fat & 1.07 & 1.07 & 0.98 & 0.85 & 0.11 \\
Protein & $0.81^{\mathrm{b}}$ & $0.81^{\mathrm{b}}$ & $0.72^{\mathrm{ab}}$ & $0.65^{\mathrm{a}}$ & 0.05 \\
Lactose & 1.33 & 1.29 & 1.18 & 1.07 & 0.08 \\
Concentration, $\%$ & & & & & \\
Fat & 3.92 & 4.13 & 4.08 & 3.95 & 0.26 \\
Protein & 2.98 & 3.15 & 2.99 & 3.00 & 0.07 \\
Lactose & 4.90 & 5.03 & 4.87 & 4.86 & 0.05 \\
\hline
\end{tabular}

${ }^{\mathrm{a}, \mathrm{b}}$ Means in a row with different superscripts differ significantly $(P<0.05)$. 
the significantly lower milk protein yield $(P<0.05)$ as DCAD increased, although previously unreported, are not necessarily in contrast with the findings of West et al. (1991) who, along with others (Escobosa et al., 1984; Delaquis and Block, 1995), found an increase in milk production and milk protein concentration with increasing DCAD. The difference may be a result of the highest DCAD in previous work being too low to identify a threshold above which a rising DCAD has a negative impact on DMI and milk production. The difference in milk protein yield in this experiment did not become apparent until the DCAD exceeded $+52 \mathrm{mEq} / 100 \mathrm{~g}$, a DCAD often exceeded in pasture-based systems. Sanchez and Beede (1994) alluded to such a negative effect when they identified an optimum DCAD for milk production of between +25 and $+50 \mathrm{mEq} / 100 \mathrm{~g}$, but data was not available to verify a negative effect by exceeding this optimum. The consequences of increasing DCAD substantially beyond $+50 \mathrm{mEq} / 100 \mathrm{~g}$ were not known from previous work.

Hydroxyproline is a biochemical marker often used for assessing skeletal turnover based on the degradation of fibrillar collagen (Robins, 1994). One procedure to determine breakdown of type 1 collagen is the measurement of Hy in urine (Russell, 1997). However, Hy may be derived from several different tissue sources such as the breakdown of collagen during uterine involution (Kaidi et al., 1991). Therefore an effect of treatment on urine Hy concentration cannot be assumed to be solely due to bone resorption without additional measurements to support this. In this experiment, $\mathrm{Hy} /$ Creat increased linearly with increasing DCAD $(P<$ 0.05 ) with no significant change in plasma or urine $\mathrm{Ca}$, suggesting that bone resorption was not the cause of the increase in Hy/Creat. This is supported by the findings of Zaporozhats (1980) but is in contrast to previous work in nonlactating cows (Block, 1984), where Hy/ Creat was found to increase as DCAD decreased. A more likely cause of the increased Hy/Creat is associated with an increased rate of hydrolysis of extraskeletal connective tissue components (Galambos et al., 1976). Hydroxyproline is also regarded as a reliable indicator of uterine involution (Kaidi et al., 1991; Abribat et al., 1992). As the cows in the current experiment were less than $35 \mathrm{~d}$ calved, they were still probably undergoing uterine involution (Miettinen, 1990). The increase in the Hy/Creat might suggest that an elevated DCAD increased the rate of uterine involution, preparing the cow for pregnancy earlier than would otherwise have occurred.

\section{CONCLUSIONS}

In pasture-based dairying systems, blood $\mathrm{pH}$ and urine $\mathrm{pH}$ are reduced when a low DCAD ration is fed, but there is a threshold level, between +52 and +102 $\mathrm{mEq} / 100 \mathrm{~g}$, above which little change in systemic $\mathrm{pH}$ occurs. Although no significant difference in milk production could be detected, the data were consistent with there being a decreased milk yield, as DCAD increased from +21 to $+127 \mathrm{mEq} / 100 \mathrm{~g}$ as well as a decrease in DMI and ADLG. Further work needs to be undertaken to determine if the trends in milk yield with a varying $\mathrm{DCAD}$, on pasture-based diets, are important. Increasing the DCAD offered to dairy cows, resulted in a significant increase in excreted hydroxyproline, probably due to an increased rate of uterine involution.

\section{ACKNOWLEDGMENT}

The authors acknowledge the technical assistance of P. Durling, G. Lineham, K. Baum, D. Wilson, J. Laidlaw, S. Laidlaw, M. Davies, and A. Green, the statistical expertise of M. Hannah and all the help afforded them by farm staff.

\section{REFERENCES}

Abribat, T., P. Julie, P. H. Lapierre, J. M. Fabre, and X. Berthelot. 1992. Measurement of hydroxyprolinaemia in the lactating cow: relationship with some post-partum pathologies. Rev. Med. Vet. 143:901-904.

Australian Government. 1990. Australian code of practice for the care and use of animals for scientific purposes. Australian Government Publishing Service, Canberra, Australia.

Baird, D. B. 1994. The design of experiments with covariates. Ph.D. Diss. University of Otago, Australia.

Bartels, H., M. Boemer, and C. Heirli. 1972. Serum creatinine determination without deproteinization. Clin. Chim. Acta 37:193-197.

Block, E. 1984. Manipulating dietary anions and cations for prepartum dairy cows to reduce incidence of milk fever. J. Dairy Sci. 67:2939-2948.

Clarke, T., P. C. Flinn, and A. A. McGowan. 1982. Low cost pepsincellulase assays for the prediction of digestibility of herbage. Grass Forage Sci. 37:147-150.

Delaquis, A. M., and E. Block. 1995. Dietary cation-anion difference, acid-base status, mineral metabolism, renal function and milk production of lactating cows. J. Dairy Sci. 78:2259-2284.

Doyle, P. T., C. R. Stockdale, and A. R. Lawson. 1996. Pastures for dairy production in Victoria. Agriculture Victoria, Victoria, Australia.

Escobosa, A., C. E. Coppock, L. D. Rowe, W. L. Jenkins, and C. E. Gates. 1984. Effects of dietary sodium bicarbonate and calcium chloride on physiological responses of lactating dairy cows in hot weather. J. Dairy Sci. 67:574-584.

Galambos, J. T., E. Dale, and F. Binkley. 1976. Plasma concentrations of connective tissue compounds: 1 . The effect of uterine involution. Pages 366-367 in Proc. Soc. Exp. Biol. Med.

Genstat V Committee. 1997. Genstat 5, Release 4.1, Reference Manual. Oxford University Press, Oxford, United Kingdom.

Harville, D. A. 1974. Nearly optimal allocation of experimental units using observed covariate values. Technometrics 16:589-599.

Hutton, J. T., and K. Norrish. 1977. Plant analyses by X-ray spectrometry. 2. Elements of atomic number greater than 20. X-Ray Spectrometry. 6:12-17.

Jacobs, J. L., and S. E. Rigby. 1999 Minerals in dairy pastures in Victoria. Department of Natural Resources and Environment, Melbourne, Australia.

Joyce, P. W., W. K. Sanchez, and J. P. Goff. 1997. Effect of anionic salts in prepartum diets based on alfalfa. J. Dairy Sci. 80:2866-2875. 
Kaidi, R., P. J. Brown, J. S. E. David, D. J. Etherington, and S. P. Robins. 1991. Uterine collagen during involution in cattle. Matrix 11:101-107.

Miettinen, P. V. A. 1990. Uterine involution in Finnish dairy cows. Acta Vet. Scand. 31:181-185.

Milestone Application Laboratory. 1995. Milestone application notes for microwave digestion. Application Note 23.

Mongin, P. 1980. Electrolytes in nutrition: review of basic principles and practical application in poultry and swine. Pages 1-15 in Proceedings of the International Mineral Conference, Orlando, FL.

Morton, J., and C. Roach. 2002. Potash-How does it affect production and cow health. Pages 19-23 in Proceedings of the Westpac Trust Dairy Conference. Taranaki, New Zealand.

National Research Council. 1989. Pages 2-51 in Nutrient Requirements of Dairy Cattle. 6th rev. ed. Natl. Acad. Sci., Washington, DC.

National Research Council. 2001. Pages 106-131 in Nutrient Requirements of Dairy Cattle. 7th rev. ed. Acad. Sci., Washington, DC.

Neuman, R. E., and M. A. Logan. 1950. The determination of collagen and elastin in tissues. J. Biol. Chem. 186:549-556.

Norrish, K., and J. T. Hutton. 1977. Plant analyses by x-ray spectrometry. 1. Low atomic number elements, sodium to calcium. X-Ray Spectrometr. 6:6-11

Parekh, A. C., and D. H. Jung. 1970. An improved method for determination of total hydroxyproline in urine. Biochem. Med. 4:446-456.

Robins, S. P. 1994. Biochemical markers for assessing skeletal growth. Eur. J. Clin. Nutr. 48:99-209.

Roche, J. R. 1999. Dietary cation-anion difference for pasture-fed dairy cows. Ph.D. Diss. University College, Dublin, Ireland.

Roche, J. R., D. E. Dalley, P. J. Moate, C. Grainger, M. Hannah, F. O'Mara, and M. Rath. 2000. Variations in the dietary cationanion difference and the acid-base balance of dairy cows on a pasture-based diet in south-eastern Australia. Grass Forage Sci. 55:26-36.

Roche, J. R., J. Morton, and E. S. Kolver. 2002. Sulfur and chlorine play a non-acid base role in periparturient calcium homeostasis. J. Dairy Sci. 85:3444-3453.

Russell, R. G. G. 1997. The assessment of bone metabolism in vivo using biochemical markers. Horm. Metabolic Res. 29:138-144.

Sanchez, W. K., and D. K. Beede. 1994. Cation-anion concepts for lactating dairy rations. Cation-anion applications for lactating dairy cattle. Pages 1-13 in Proceedings of Mallinckrodt Feed Ingredients Conference. Rochester, NY.

Schneider, P. L., D. K. Beede, and C. J. Wilcox. 1986. Responses of lactating cows to dietary sodium source and quantity and potassium quantity during heat stress. J. Dairy Sci. 69:99-110.

Standing Committee on Agriculture 1990. Feeding Standards for Australian Livestock-Ruminants in Ruminants. Ruminants Subcommittee, eds. Melbourne, Australia: CSIRO Publications.

Stewart, P. A. 1981. How to Understand Acid-Base-A Quantitative Acid-Base Primer for Biology and Medicine. Edward Arnold, London.

Stewart, P. A. 1983. Modern quantitative acid-base chemistry. Can. J Physiol. Pharm. 61:1444-1461.

Tietz, N. W. 1987. The fundamentals of clinical chemistry. W. B. Saunders, Philadelphia.

Tucker, W. B., G. A. Harrison, and R. W. Hemken. 1988. Influence of dietary cation-anion balance on milk, blood, urine and rumen fluid in lactating dairy cattle. J. Dairy Sci. 71:346-354.

Tucker, W. B., J. F. Hogue, D. F. Waterman, T. S. Swenson, Z. Xin, R. W. Hemken, J. A. Jackson, G. D. Adams, and L. J. Spicer. 1992. Sulfur should be included when calculating the dietary cation-anion balance of diets for lactating dairy cows. Pages 141150 in Anim. Sci. Res. Report, Oklahoma Research Station.

West, J. W. 1993. Cation-anion balance: its role in lactating cow nutrition. Pages 14-15 in Feedstuffs. 10 May, 1993.

West, J. W., B. G. Mullinix, and T. G. Sandifer, 1991. Changing dietary electrolyte balance for dairy cows in cool and hot environments. J. Dairy Sci. 74:1662-1674.

West, J. W., K. D., Haydon, B. G., Mullinix, and T. G. Sandifer. 1992. Dietary cation-anion balance and cation source effects on production and acid-base status of heat stressed cows. J. Dairy Sci. 75:2776-2786.

Wheeler, W. E., and R. L. Hruska. 1981. Importance of cation-anion balance in ruminant nutrition. Pages 17-26 in Proc. Georgia Nutrition Conference.

Yen, J. T., W. G. Pond, and R. L. Prior. 1981. Calcium chloride as a regulator of feed intake and weight gain in pigs. J. Anim. Sci. 52:778-782.

Zaporozhats, N. F. 1980. Metabolism of basic macroelements in lactating cows grazed on pastures with high doses of mineral fertilisation. Pages 16-19 in Byulleten' Vsesoyuznogo Nauchno issledovatel'skogo Instituta Fiziologii, Biokhimii I Pitaniy. No. 2-58. 